NEULINGER Ágnes

TÖBB-MÓDŞZERTANÚ ÉS VEGYES MÓDSZERTANÚ KUTATÁSOK

\author{
KORREFERÁTUM SIMON JUDIT „KUTATÁS-MÓDSZERTANI \\ TRENDEK A MARKETINGBEN" CÍMÜ TANULMÁNYÁHOZ
}

\begin{abstract}
A marketingkutatás területét - más üzleti területekhez hasonlóan - markánsan érintik az elmúlt időszak társadalmi-gazdasági változásai. A kutatásmódszertan ennek megfelelóen változik és ez a változás részben azt is jelenti, hogy a korábbi éles határok egyes módszertani területek között, úgymint a kvalitatív és kvantitatív megközelítések, elhalványulnak. Jelen tanulmány a több-módszertanú és vegyes módszertanú kutatásokat vizsgálja, illetve értelmezi ezeket az aktuális kutatás-módszertani trendek kapcsán.
\end{abstract}

Kulcsszavak: marketingkutatás, trendek, kvalitatív, kvantitatív, vegyes módszertan, korreferátum

A marketingkutatás központi értéke a döntéstámogatás. Az üzleti élet képviselói a marketingkutatás által nyújtott információk és insightok segítségével jobb (és ezzel vélhetôen nagyobb profitot is eredményező) döntéseket hozhatnak, míg a tudományos kutatók közelebb juthatnak valamely koncepció leírásához, megértéséhez, előrejelzéséhez. Kétségtelenül az utóbbi évtizedek társadalmi-gazdasági változásai befolyásolják a marketingkutatás módszertanát, hiszen olyan trendek mellett, mint a technológiai fejlődés és a megváltozó fogyasztói magatartás nem mehet el a szektor. Ugyanakkor a kutatásmódszertan alkalmazkodása e trendekhez sokszor nehézkes és ellentmondásos, hiszen a kutatás a döntéshozatal kockázatának csökkentését célozza, így módszertanában ötvöznie kell a változásokhoz való alkalmazkodást azokkal a konzervatív elvekkel, amelyek a kutatási eredmények érvényességét és megbízhatóságát biztosítják. Simon Judit vitaindító tanulmánya a kutatás-módszertani trendek kapcsán értelmezi a globalizálódó piac kihívásait, a technológiai fejlődés következményeit és követelményeit, a társadalmi változások hatását, valamint a vállalati szféra változásait. Jelen tanulmány keretein túlnyúlik, hogy minden felvetett kérdésre reagáljon, így egy választott kérdés alaposabb kidolgozására koncentrál. Ennek megfelelően a tanulmány a marketingkutatás trendjei közül a több-módszertanú és vegyes módszertanú hibrid kutatások bemutatására fókuszál.
Hibrid kutatások, azaz kutatások több- és vegyes módszertannal

A hibrid kutatás különböző kutatási módszertanok együttes alkalmazását jelenti. Hibrid kutatás megvalósulhat több eltéró, de kizárólag kvalitatív vagy kvantitatív megközelítés/ adatfelvétel kombinációjával, továbbá vegyesen, azaz a kvalitatív és kvantitatív módszertan összekapcsolásával. Az eltérő megoldások kombinálása lehet szekvenciális és párhuzamos. Előbbi esetében az egyik megoldást a másik megoldás alkalmazása időben követi, míg utóbbinál ezek párhuzamosan kerülnek lebonyolításra. Harrison és Reilly (2011) elemzése szerint a marketing területén leggyakrabban több-módszertanú (multi-method) és vegyes módszertanú (mixed method) kutatásnak hívják ezt a megközelítést, de a társadalomtudományok területén további elnevezésekkel is találkozhatunk, úgymint kevert kutatás, integratív, több-módszerú megközelítés, többszörös módszerek, háromszögelő vizsgálatok, vegyes kutatás ${ }^{1}$. Morse (2003) meghatározását követve a két fogalom között a legfontosabb különbség, hogy a több-módszertanú (multi-method) megközelítés egy kutatáson belül többféle kvalitatív vagy többféle kvantitatív felmérést használ, míg a vegyes módszertanú (mixed method) többféle típusú adatot kapcsol össze. Utóbbi esetében a legjellemzőbb a kvalitatív és kvantitatív módszer együttes használata egy kutatáson belül. Érdemes azonban azt is megjegyezni, hogy a megfogalmazások használata nem 
egységes és az is változó, hogy az egyes szerzők éppen mit értenek több-módszertanú és vegyes módszertanú kutatás alatt. Jelen tanulmány a fenti Morse (2003) definícióhoz igazodik.

\section{A több-módszertanú kutatás}

Amennyiben több-módszertanú kutatást használunk, akkor alkalmazhatunk olyan hibrid mintát, ahol a válaszadókat egynél több adatfelvételi módon érjük el, de mindenkit csak egyféle módon kérdezünk meg vagy olyan hibrid mérést, ahol ugyanaz a válaszadó többféle adatfelvételi technikával egyaránt találkozik, fogalmazza meg Pintér Róbert és Kátay Bálint (2010) a kvantitatív több-módszertanú kutatások kapcsán. A hazai és nemzetközi tapasztalatok szerint ezeket a kutatásokat elsősorban a válaszadási hajlandóság javítása és a mintaméret/reprezentativitás javítása ösztönözi (Molloy - Macer, 2009; Pintér - Kátay, 2010). A több-módszertanú kvantitatív kutatás során a kutatók gyakran a kérdőíves kutatást kombinálják valamilyen másik kvantitatív módszerrel, így például kísérlettel vagy valamilyen múszeres méréssel, erre példa Kemény Ildikó (2015) hazai kutatása is.

Természetesen több-módszertanú kutatás nemcsak kvantitatív, hanem kvalitatív kutatások esetében is elvégezhető. Ilyen megközelítést alkalmazott Metzler és Davis (2002), akik kvantitatív kutatásuk megalapozásához két kvalitatív adatfelvételi technikát (személyes és on-line mélyinterjúk, majd fókuszcsoport) kombináltak. Mivel a kvalitatív fázis célja a követô kérdőíves kutatás kérdő́ivének kidolgozása volt, így kutatásuk olyan hibrid kutatás volt, amelyben több- és vegyes módszertannal is dolgoztak. A több-módszertanú kvalitatív kutatások kihívásai jellemzóen hasonlóak a korábban bemutatott kvantitatívhoz, de külön kiemelhetó a válaszadási helyzet érzékenysége a válaszokra, amit az elemzés során figyelembe kell venni és kezelni kell (Poynter és szerzőtársai, 2014).

\section{A vegyes módszertanú kutatás}

A vegyes módszertanú kutatás a kvalitatív és kvantitatív módszer kombinálását jelenti. A kvalitatív és kvantitatív kutatás ötvözését azonban megnehezíti, hogy kutatási kérdéseiket eltéró paradigmában fogalmazzák $\mathrm{meg}^{2}$, ahogy arra Simon Judit is utal tanulmányában. Amíg a kvantitatív kutatás strukturált módszer, amelyet jellemzően nagy és reprezentatív mintán végeznek el a vizsgált sokaság statisztikai jellemzésére és az azonosított összefüggések számszerúsítésére, addig a kvalitatív kutatás nem törekszik számszerúsítésre és általánosításra. Amennyiben a kvalitatív és kvantitatív üzleti kutatásokra fordított összegeket tekintjük, akkor az ESOMAR éves jelentések alapján $(2005,2014)$ elmondható, hogy globálisan az üzleti kutatási kiadások nagyrésze kvantitatív kutatásokra jut, ennek aránya 74\% volt 2014ben, miközben kvalitatív kutatásokra $16 \%$ fordítódott. A maradék, amely elsősorban szekunder elemzést jelent, jelentôsen bővült az elmúlt tíz évben és 2014-ben már 10\%-át tette ki a kutatási költéseknek.

Nem egyértelmú ugyanakkor, hogy a kvalitatív és kvantitatív kutatás határozott szétválasztása - amely az ESOMAR-jelentésben is megjelenik - valóban ilyen éles-e. A posztmodern perspektíva - amely képes a ma fogyasztójának létét megragadni - új távlatokat nyitott a jelenségek megmérésére és megértésére, amelyben a kvalitatív és kvantitatív adat nem feltétlenül válik szét és lehetséges egyszerre mindkét nézôpont alkalmazása és az elemzésben való megjelenítése. A vegyes módszertan alkalmazásának elsődleges motivációja a kutatási kérdés minél teljesebb körú megválaszolása és megalapozottabb következtetések levonása. A megközelítést a tudományos kutatások esetében ösztönözi az is, hogy a két módszertan együttes használatával egyszerre biztosítható egy koncepció mély megértése, miközben pontos statisztikai elemzések is elvégezhetők. Utóbbit a tudományos közeg előszeretettel preferálja és sokszor el is várja, így a vegyes kutatásmódszertan alkalmazásával ennek az elvárásnak is meg lehet felelni.

Brymann (2006) 232 darab társadalomtudományi tanulmány tartalomelemzése alapján a vegyes módszertan használatának tizenhat okát azonosította olyan kutatások esetében, amelyek kombinálták a kvalitatív és kvantitatív megközelítést és 1993-2004 között jelentek meg. Az általa nevesített tizenhat indok három nagyobb csoportba sorolható, úgymint az érvényesség biztosítása, a mélyebb megértés elérése és a fejlesztés, egymásra építkezés. Harrison és Reilly (2011) 20032009 közötti időszakra vonatkozóan és tartalomelemzés segítségével értékelte azokat a vegyes módszertant használó kutatásokat, amelyek vezető marketing-folyóiratokban jelentek $\mathrm{meg}^{3}$. Eredményeik szerint a legtöbb tanulmány (79\%) szekvenciálisan alkalmazta a vegyes módszertant, továbbá 19\%-uk egyidejüleg bonyolította a két megközelítést, míg egy esetben mind a két megoldás alkalmazásra került. Az elemzett tanulmányok többsége feltáró kutatást végzett a vegyes módszertan segítségével (47\%), a tanulmányok 25\%-a magyarázó jellegú volt, $14 \%$-uk esetében a két megközelítés egymásba ágyazva támogatta egymást, továbbá 12\%-ban a kvalitatív és kvantitatív adatfelvétel párhuzamosan futott, majd az adatok egyesítésre kerülttek és egyben kerültek elemzésre vagy az interpretáció során erősítették egymást.

Áttekintve a fentieket felmerülhet a kérdés, hogy mindebben hol az újdonság, hiszen a kvalitatív és kvantitatív kutatások együttes használata nem újkeletú. A választ erre a felvetésre Teddlie és Tashakkori (2003) a két módszer együttes kezelésének minőségével adja 
meg. Eszerint csak akkor beszélhetünk vegyes módszertanú kutatásról, ha egy projekten belül szervesen egybeépül a kvalitatív és kvantitatív módszer alkalmazása. Amennyiben az elemzés ugyan használja mind a két típusú adatot, de azokat nem integrálva kezeli, akkor az nem felel meg a vegyes kutatási módszertan elvárásainak.

A vegyes módszertan megvalósítására több lehetôség is kínálkozik. A kvalitatív és kvantitatív megközelítés közötti határok akkor maradnak meg a legszorosabban, ha a két módszertan egy projekten belül ugyan, de csak egymásra építkezik, azaz mind a két adathalmaz a maga paradigmáján belül kerül elemzésre és az összefüggések csak az interpretáció szintjén jelennek meg. A határok ott a leghalványabbak, ahol a kvalitatív és kvantitatív adatok integráltan kerülnek elemzésre és a megértés egyszerre jelenik meg a statisztikai számszerúsítéssel együtt. Ennek egyik példája a tartalomelemzés, azaz valamilyen dokumentum, szöveg vagy képi anyag megfigyelése és elemzése (Mitev, 2014). A tartalomelemzés részben objektív, szisztematikus és számszerúsítő (Kassarjian, 1977), részben kvalitatívan értelmező (Mayring, 2000). Eszerint a kvalitatív és kvantitatív elemzés egy tartalom vonatkozásában egyszerre megjelenhet lehetóséget adva a vegyes módszertan alkalmazására.

További megoldás, amikor a mérőeszköz mind kvalitatív, mind kvantitatív mérést lehetővé tesz. Erre ad példát a magyar részvétellel is lezajlott COBEREN ${ }^{4}$ projekt empirikus kutatása. A projekt on-line adatfelvétele dominánsan kvantitatív volt, de a vizuális kutatásmódszertan beépítése a kvalitatív elemzést is lehetôvé tette. A kutatás az úgynevezett képfal technikát használta, ahol a válaszadó feladata az volt, hogy a feltett kérdéshez kötődóen válasszon meghatározott számú képet egy sokféle képet tartalmazó „falról”. A képekkel támogatott kutatás népszerú a társadalomtudományi kutatásokban, ahol a kutatás során használt képek származhatnak a nyomtatott médiából, digitális kép adatbázisokból és az interneten elérhetô képanyagból egyaránt (Horváth - Mitev, 2015). A kvalitatív jellegú kérdést zárt kérdések követték a kérdőívben és ezek a kérdések tették ki a kérdôív jelentős részét. Azáltal, hogy a mérés egyszerre gyújtött kvalitatív és kvantitatív adatot lehetôvé tette a válaszadók véleményének többszempontú megértését. Az elemzés során a kétféle adatot integráltan dolgozták fel, ahol a kvalitatív adatok kódolt változatát egyrészt beépítették a kvantitatív összefüggés vizsgálatába, másrészt a kvalitatív adatok a leíró és illusztráló részben is megjelentek. Hasonló megközelítést használtak kutatásukban Albert és szerzőtársai (2008), akik a márkákhoz való viszony megértését és a márkák szeretetét mérték a kvalitatív és kvantitatív technikák ötvözésével.
A kvalitatív és kvantitatív adatfelvétel integrálása üzleti szempontból is vonzó, hiszen gyorsabb és költséghatékonyabb lehet, miközben mindkét megközelítés erôsségét kihasználja. Gyakori megoldás, hogy a kvantitatív adatfelvétel kérdőívébe kvalitatív elemzést igénylő kérdés kerül (mint fent) vagy a kvantitatív fázist interpretatív céllal egészítik ki a kvalitatívval ${ }^{5}$ és ekkor a kérdőív egyszerre a kvalitatív fázis szúrőkérdőívét is adja. A kérdőív válaszai alapján leválogatott fogyasztókkal készülhet ezután mélyinterjú, amely akkor lesz igazán idő- és költséghatékony, ha digitális platform (például videóinterjú) segítségével a kérdőív kitöltése után azonnal lebonyolítják. Üzleti szempontból az is az előnyök között található, hogy Bryson (2015) szerint a kvalitatív jellegú kérdések és a kérdőívhez kapcsolt videók élőbb, érdekesebb és nagyobb elköteleződést kiváltó kutatási jelentések készítését teszik lehetôvé.

\section{Zárógondolatok}

A marketingkutatás során mindig azt a megoldást keressük, amely adott kutatási kérdésre és adott célcsoport vonatkozásában a legjobb eredményt adja. A társadalmi-gazdasági változások, az egyetlen jó megoldást nélkülöző posztmodern perspektíva kiegészülve a technológiai fejlődéssel új kihívások elé állítja a marketingkutatást. A hibrid kutatások - mind a több-módszertanú, mind a vegyes módszertanú kutatások révén - alkalmasak arra, hogy hozzáférjenek azokhoz az információkhoz, amivel a társadalom, benne a fogyasztáshoz kötődő kérdések megérthetôk és megmagyarázhatók. A hibrid kutatások többlábon álló megközelítésével elérhetőek lesznek a nehezen elérhető csoportok és hozzáférhetővé válnak a nehezen hozzáférhető és részletes információk, hiszen az eltérő kutatási módszerek rugalmas kombinációja a megismerés határait kitágítja. Ráadásul a hibrid kutatás kihasználva a technológiai fejlődést jól illeszkedik azokhoz az elvárásokhoz is ${ }^{6}$, amelyek napjaink üzleti és akadémiai kérdéseit jellemzik.

\section{Lábjegyzet}

\footnotetext{
${ }^{1} \mathrm{Az}$ angol elnevezések a magyar leírás sorrendjében: blended research, integrative, multi-method, multiple methods, triangulated studies, mixed research.

${ }^{2}$ Koltai és szerzőtársai (2015) a kvalitatív és kvantitatív megközelítéshez kapcsolódóan említik, hogy egy kutatás során cél az alkalmazott mérés és a megfogalmazott következtetések lehető legmagasabb szintű érvényességének és megbízhatóságnak a biztosítása.

${ }^{3}$ Az elemzés a következő lapokra terjedt ki: Journal of Consumer Research, Journal of Marketing, Journal of Marketing Research, Journal of the Academy of Marketing Science, Journal of Retailing, Journal of Consumer Psychology, Marketing Science, International Journal of Research in Marketing, és European Journal of Marketing.

${ }^{4}$ A COBEREN (COnsumer BEhaviouR Erasmus Network) fogyasztói magatartással foglalkozó kutatók hálózata. A hálózatnak 36 partnerintézmény a tagja, összesen 28 európai országból. Magyarországot a Corvinus
} 
Egyetem képviselte. A projektet 2009 és 2012 között támogatta az Európai Unió.

${ }^{5}$ Erre ad példát Neulinger Ágnes és Zsótér Boglárka (2013) kutatása.

${ }^{6}$ Lásd például Keszey Tamara (2011) tanulmányát.

\section{Felhasznált irodalom}

Albert, N. - Merunka, D. - Valette-Florence, P. (2008): When consumers love their brands: Exploring the concept and its dimensions. Journal of Business Research, 61(10): p. 1062-1075.

Bryman, A. (2006): Integrating quantitative and qualitative research: how is it done? Qualitative Research, 6(1): p. 97-113.

Bryson, J. (2015): The Coming of Quant+Qual Integrated Research. http://qualblog.com/the-coming-of-quantqual-integrated-research/\#comments, leöltve 2015-11-02

ESOMAR (2014): Global Market Research 2014 - An ESOMAR Industry Report. ESOMAR, Amsterdam, The Netherlands

ESOMAR (2005): Global Market Research 2005 - Esomar Industry Report. ESOMAR, Amsterdam, The Netherlands

Ganassali, S. - Rodriguez-Santos, C. (2013): Research Intentions are Nothing without Technology: Mixed-Method Web Surveys and the Coberen Wall of Pictures Protocol. in: N. Sappleton (szerk.): Advancing Research Methods with New Technologies. Hershey, PA: Information Science Reference: p. 138156. doi:10.4018/978-1-4666-3918-8.ch008

Harrison, R. L. - Reilly, T. M. (2011): Mixed methods designs in marketing research. Qualitative Market Research: An International Journal, 14(1): p. 7-26.

Horváth Dóra - Mitev Ariel (2015): Kollázstechnika, képasszociációk. in: Horváth Dóra - Mitev Ariel (2015): Alternatív kvalitatív kutatási kézikönyv. Budapest: Alinea Kiadó: p. 337-354.

Kassarjian, H.J. (1977): Content Analysis in Consumer Research. Journal of Consumer Research, 4: p. 8-18.

Kemény Ildikó (2015): A versenytársak csak egy kattintásra vannak - Az újravásárlási és továbbajánlási szándék alakulása különböző e-kereskedelmi kategóriákban. Doktori disszertáció. Budapest: BCE Gazdálkodástani Doktori Iskola

Keszey Tamara (2011): How market information is transformed into marketing knowledge? Acta Oeconomica, 61(3): p. 313-336.
Koltai Júlia - Sik Endre - Simonovits Bori (2015): A kvali-kvanti áldilemmán túl. Szociológiai Szemle, 25 (2): p. 31-49.

Mayring, Ph. (2000): Qualitative Inhaltsanalyse. Grundlagen und Techniken (7th edition, first edition 1983). Weinheim: Deutscher Studien Verlag

Metzler, D. P. - Davis, P. C. (2002): Employing a mixed-mode qualitative research method prior to conducting quantitative research. International Conference on Improving Surveys. http://www.websm. org/db/12/1280/rec, letöltve 2015-11-04

Mitev Ariel (2014): Megfigyelés és kísérlet. in: Gyulavári Tamás - Mitev Ariel - Neulinger Ágnes Neumann-Bódi Edit - Simon Judit - Szúcs Krisztián (2014): A marketingkutatás alapjai. Budapest: Akadémiai Kiadó: p. 123-148.

Molloy, P. - Macer, T. (2009): Where We Are and Where We Might Be Going. Trends in Marketing Research Technology. CASRO 14th Technology Conference. New York. Május 28-29. http://www. meaning.uk.com/resources/articles_papers/files/ CasroTech09-Software-survey-presentation-Molloy-and-Macer.pdf, letöltve 2015. október 29.

Morse, J. M. (2003): Principles of mixed methods and multimethod research design. in: Tashakkori, A. Teddlie, C. (szerk.): Handbook of Mixed Methods in Social and Behavioral Research. Thousand Oaks, CA: Sage: p. 189-208.

Neulinger Ágnes - Zsótér Boglárka (2013): A családi fészekben élő fiatal felnőttek és fogyasztói döntéseik. Vezetéstudomány, 9: p. 22-34.

Pintér Róbert - Kátay Bálint (2010): A hibrid adatfelvétel módszertani kihívásai. Statisztikai Szemle, 88 (7-8): p. 723-738.

Poyter, R. (2015): Envisioning 2025: Five Technology Changes That Will Reshape Customer Behavior And What They Mean For Customer Intelligence. http://www.greenbookblog.org/2015/08/26/envisioning-2025-five-technology-changes-that-will-reshape-customer-behavior-and-what-they-mean-for-customer-intelligence, letöltve 2015-11-03

Teddlie, C. - Tashakkori, A. (2003): Major issues and controveries in the use of mixed methods in the social and behavioral sciences. in: Tashakkori, A. -Teddlie, C. (szerk.): Handbook of mixed methods in social \& behavioral research. Thousand Oaks, SAGE: p. 3-50. 